\title{
Comparison of the Herbal Care Package and Breast Care Method On Volume Of Breast Milk Among Postpartum Mothers With Breast Engorgement
}

\author{
Ihrom Fatma Saputri*, Suharyo Hadisaputro, Diyah Fatmasari \\ Poltekkes Kemenkes Semarang, Semarang, Indonesia \\ *saputrifatmaihrom@gmail.com
}

\begin{abstract}
Warm herbal ball compress were alternative treatments on increase volume of breast milk. Cold cabbage leaves to reduce breast pain. Combination of two non pharmacology methods will be more effective to reduce breast pain and increase volume of breastmilk. The study aimed to analyze difference effect of herbal care package than breastcare to volume of breast milk. The design study conduct quasi experiment with pretest-posttest with a non-equivalent control group. The subject is 30 postpartum mothers day 1-14 with breast engorgement in Semarang. The intervention group was applied warm herbal ball compresses, breast massage, and cold cabbage. However control group was applied breastcare. Both groups received these treatment 6 times during 3 days with duration of 20 minutes. Electric breast pump and beaker glass was instruments to observed volume of breast milk.

The results of the dependent statistical test showed intervention group increased volume of breast milk $15.27 \mathrm{ml}$ to $53.6 \mathrm{ml}$ with mean difference of 38,33. The control group increased volume of breast milk $16.13 \mathrm{ml}$ to $37.93 \mathrm{ml}$ with mean difference of $21.80 \mathrm{ml}$. Independent t-test results obtained p-value 0.001. Herbal care package can increase volume of breast milk than breastcare.
\end{abstract}

Keywords : Breast Engorgement, Breast Care, Herbal Care 


\section{STRADA Jurnal Ilmiah Kesehatan}

DOI: $10.30994 /$ sjik.v9i2.387

ISSN: 2252-3847 (print); 2614-350X (online)

Vol.9 No.2 November 2020 Page.813-819

\section{BACKGROUND}

Breast milk is the best nutrition for babies during the first six months of life until a child is two years old.The coverage of breastfeeding in Indonesia for 2016 until 2018 was $29.5 \%, 35.7 \%$ and $37.3 \%$ (Kemenkes, 2018a). Central Java was 41.8\% in 2017. The city of Semarang is $31.9 \%$. It is still below standard Ministry of Health 50\% (Kemenkes, $2018 \mathrm{~b}$ ). One of many problems in the postpartum period is breast engorgement (Prawirohardjo, 2014). The incidence of breast engorgement around 20\% to 70\% in third to fourteenth postpartum day (Pamela Berens, 2016). Breast engorgement is a physiological condition where breast milks blocked in the milk ducts, alveolus and vascular congestion, and interstitial edema. Signs and symptoms of breast engorgement is hard breast, breast pain, swollen breast, fever and decrease breast milk (Alekseev et al., 2015). Odom prove that breast swelling is a factor that caused mothers to stop of breastfeeding(10.9\% and 5.7\%; OR 1 , 97; P <0.02) (Odom et al., 2013).

Paracetamol was medical treatment to reduce breast pain. Serrapeptase (danzen) was antiinflammatory medications (Pamela Berens, 2016). Both of them drugs did not reduce of breastmilk production. It determine blood clotting process. Several non pharmacological treatments to reduce breast engorgement were breast massage, warm compresses, breast care method, cold cabbage, and warm herbal ball compresses (Mangesi \& Zakarija Grkovic, 2016).

Breast care method is breast massage combined with warm and cold compresses (Bahiyatun, 2013). It recommended to increase of breastmilk. The disadvantage of breast care is pain management. Breast care method did not effective to reduce breast pain in postpartum mothers with breast engorgement (Lim et al., 2015). Herbal medications are recommended as alternative treatments in the world today. Various herbs including phlai, turmeric, lemon grass and cabbage (Ketsuwan et al., 2018). Herbal ball compresses were alternative treatments to stimulated vasodilation of blood vessels, milk ducts, reduce breast swelling and stimulated breast milk production (Dhippayom et al., 2015). Cold cabbage compress effectiveness blocks breast pain to the hypothalamus(ElSaidy \& Aboushady, 2016). Combination more than two non pharmacology methods will be more effective to reduce breast pain and increase volume of breast milk.(Pamela Berens, 2016)

Both pharmacologic and nonpharmacologic treatment can reduce breast engorgement symptoms. However, It was a physiological condition after delivery. So, postpartum mothers did not always require treatment with pharmacologic treatment. (Mangesi \& Zakarija Grkovic, 2016) Nonpharmacologic treatment including breast care methods and herbal care needed more evidence based investigation. We are interested in the comparisons of herbal care and breast care method as seen in this study.

The study aimed to examine the effect of the herbal care packages and breast care nonpharmacologic method on volume of breast milk.

\section{METHODS}

\section{Research design}

The design study conduct quasi experiment with pretest-posttest with a nonequivalent control group. The intervention group received herbal care package. While the Herbal care package consists of warm herbal ball compress for 5 minutes, breast massage for 5 minutes and cold cabbage leaf compresses for 10 minutes. Before treatment, herbal ball were steamed for 15 minutes at temperature of $43-46^{\mathrm{O}} \mathrm{C}$. Meanwhile, cabbage leaves were soaked into cold water at temperature of 10-18 C for 15 minutes. 


\section{STRADA Jurnal Ilmiah Kesehatan}

DOI: $10.30994 /$ sjik.v9i2.387

ISSN: 2252-3847 (print); 2614-350X (online)

Vol.9 No.2 November 2020 Page.813-819

The control group was given breast care. Breast care consisting of breast massage for 5 minutes, warm compress for 5 minutes, and cold compress with small towels for 10 minutes. Both groups received these treatment 6 times during 3 days with total duration of 20 minutes. Before treatment, small towel soaked in to warm water with temperature of 43-46 C and 10-18 C for cold water.

\section{Setting, samples, sampling technique}

The samples of this study is 30 postpartum mothers in $1-14^{\text {st }}$ day with breast engorgement. This study was conducted in the community health center in Semarang from April to June 2019. We recruited 30 samples and 15 samples were allocated in the experimental group and control group. The technique of sampling is purposive sampling. The study inclusion criteria for the mothers who were in the 1 st to 14 th days after delivery consisted of having breast engorgement, temperature below $38 \mathrm{C}$, having breast engorgement symptoms, spontaneous delivery. The study exclusion criteria for mother of the incidence of allergy to cabbage leaves, no use of medications like analgesics and suppression of lactation, not having breast abscess or mastitis, a general temperature exceeding $38 \mathrm{C}$ after beginning the intervention.

\section{Instruments}

The research instruments used in this study are as follows: 1) Six points engorgement scale. This tool designed by Hill and Humenick to measure breast engorgement grade.(Hill \& Humenick, 1994). 2) Observation sheet about characteristics of the mothers includings age, number of postpartum days, parity, duration of breastfeeding, and frequency of breastfeeding.

3) Standard Procedures herbal care packages and breast care method. 3)Instruments to pump breast milk volume is electric breast pump. Electric breast pump was used for 10 minutes to measure volume breast milk. Beaker glass was standardized reliable tool for assessing volume of breast milk. It had an accuracy level of $0.1 \mathrm{ml}$.(Panwara et al., 2016)

\section{Ethical consideration}

This research was registered at Dr. Moewardi Health Research Ethics Commission with number 451/IV/ HREC /019.

\section{Data analysis}

Data analysis used with paired t-test to and independent t-test. The paired t-test to analyze effect before and after given herbal care package and breastcare. The independent t-test to compare herbal care packages versus breastcare method to increase volume of breast milk. 


\section{STRADA Jurnal Ilmiah Kesehatan}

DOI: $10.30994 /$ sjik.v9i2.387

ISSN: 2252-3847 (print); 2614-350X (online)

Vol.9 No.2 November 2020 Page.813-819

\section{RESULTS}

The result of this study were presented as below:

Table 1. Comparison of Volume of breast milk Before and After Treatment

\begin{tabular}{lccc}
\hline \multicolumn{1}{c}{ Variabel } & $\begin{array}{c}\text { Intervention } \\
(\mathrm{n}=15)\end{array}$ & $\begin{array}{c}\text { Control } \\
(\mathrm{n}=15)\end{array}$ & $p$ \\
\cline { 2 - 3 } & Mean $\pm \mathrm{SD}$ & Mean $\pm \mathrm{SD}$ & \\
\hline $\begin{array}{l}\text { Volume of breast milk (ml) } \\
\text { pre }\end{array}$ & $15.27 \pm 4.04$ & $16.13 \pm 5.06$ & $0,609^{c}$ \\
$\quad$ post & $53.60 \pm 14.02$ & $37.93 \pm 9.89$ & $0,001^{c}$ \\
$\begin{array}{l}p \text {-value } \\
\text { mean difference }\end{array}$ & $0,000^{a}$ & $0,000^{a}$ & \\
\hline
\end{tabular}

Note: $a=$ paired $t$-test. $c=$ independent $t$-test

Table 1 explained the results of the dependent t-test analysis showed that in the intervention group the average volume of breastmilk before intervention was $15.27 \mathrm{ml}$ and after intervention was $53.60 \mathrm{ml}$. The result with paired t-test ( $\mathrm{p}$-value <0.05) which means that there is a difference in volume of breast milk before and after in the intervention group. In the average control group before intervention was $16.13 \mathrm{ml}$ and after intervention was $37.93 \mathrm{ml}$ with p-value <0.05, which means that there is a difference in volume of breast milk of the control group before and after given by breastcare method.

Figure 1.

The mean difference before and after treatment between intervention group and control group.

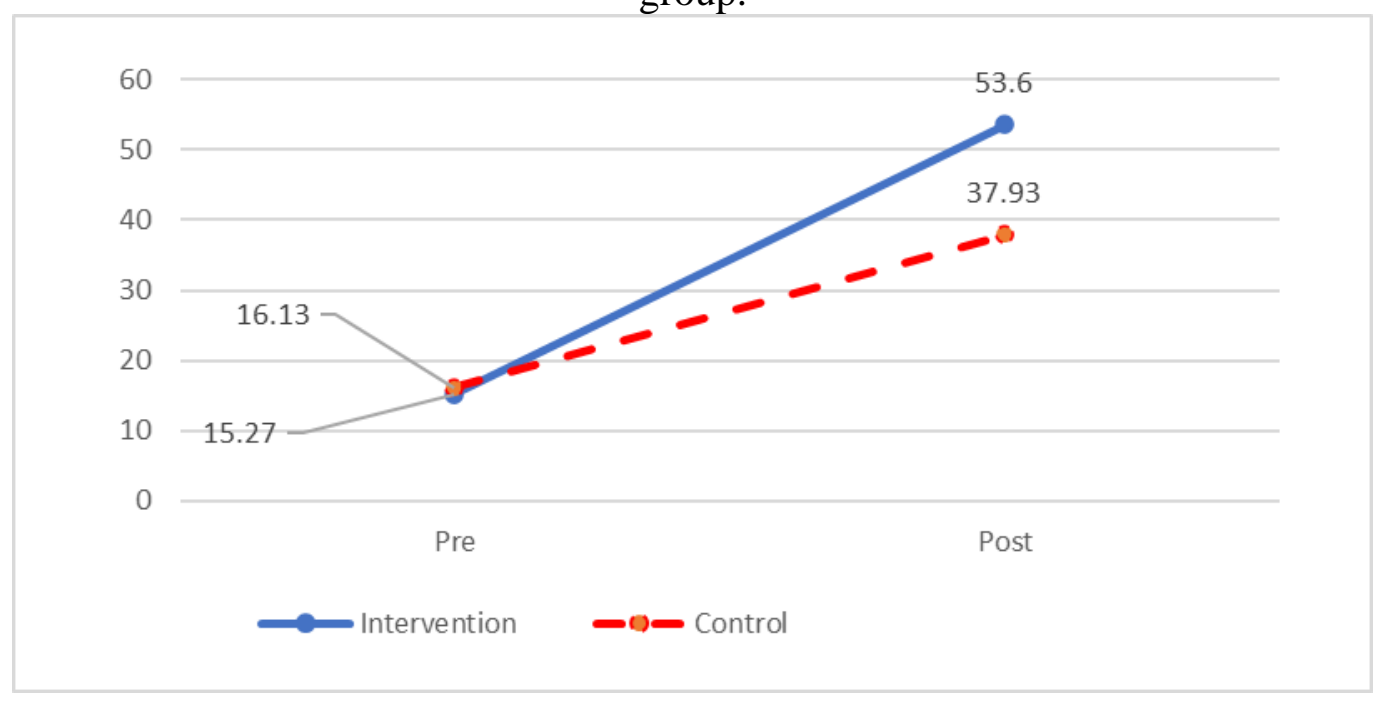

The difference mean of volume of breast milk in the intervention group (herbal care) was $38.33 \mathrm{ml}$ and the control group (breastcare) was $21.80 \mathrm{ml}$. The result of $p$ value $=0.001$, which means that there are differences on volume of breastmilk between intervention and control groups. The mean of volume breast milk in intervention group was higher than breastcare group. 


\section{STRADA Jurnal Ilmiah Kesehatan}

DOI: $10.30994 /$ sjik.v9i2.387

ISSN: 2252-3847 (print); 2614-350X (online)

Vol.9 No.2 November 2020 Page.813-819

\section{DISCUSSION}

Case of breast engorgement at postpartum mothers often occur on the third to sixth day after delivery (Manna et al., 2016). Signs and symptoms of breast engorgement are breast swelling, breast pain. Factors of breast engorgement were age, parity, type of delivery, frequency of breastfeeding, duration of breastfeeding, nutrition of mothers, and maternal psychology (Alekseev et al., 2015).

Treatments of herbal care packages consists of warm herbal ball compresses, breast massage, and cold cabbage compresses. Warm herbal ball compresses consist of bengle, turmeric, lemongrass, orange leaves, tamarind leaves, salt and champor.

The result proved that volume of breast milk in herbal care packages group was higher than breastcare group. It was several strengths. Warm herbal ball compresses will activate the hormone oxytocin to do let down reflexes. Warm herbal ball compresses can stimulate vasodilation of blood vessels, to make smooth circulation of breastmilk in lactiferous ducts and relax tense muscles (Soonanond, 2014). Another advantage of warm herbs, It can stimulate hypothalamus to release endorphins hormone. It became rilex and reduce breast pain.(Trainapakul et al., 2010).

Cold cabbage leaves were reduced temperature of breasts tension in the alveoli cell wall. The effect of cold cabbage can blocked the transmission pain to the brain. So, it reduced breast pain. Another advantage of cold cabbage leaves compress were content in the leaves like sulforafan, vit A, C, K, methionine acid and glutamine. It made to absorb fluid in the breast. So It can to reduce breast hardness (Disha et al., 2015).

Breastcare were one of method to increase volume of breast milk.(Pamela Berens, 2016) Breastcare consist of breast massage combine with warm and cold compresses. Combination of techniques based on pressure and touch to the breast skin. It to make comfortable impulses to the hypothalamus. The hypothalamus will stimulate the posterior pituitary to release of the hormone oxytocin. After that, oxytocin hormone can secrete more breast milk (Maritalia, 2012).

The stimulation of breast massage at three points on the breast. The point above nipple, the point on nipple and the point below nipple. The point above nipple can influence the pituitary to produce prolactin hormon. Prolactin hormone stimulated to increase breast milk production (Witt et al., 2016). Warm stimulation in breastcare method occurs after \pm 20 sequences. So it required more time for stimulate impulse distribution than warm herbal compresses.(Novita, 2011)

Warm and cold compresses on the breastcare method to reduce temperature of breast skin. The warm effect used for stimulating vasodilation of the breast milk. It stimulated releasing of hormone oxytocin.It can stimulate the expenditure of milk and improved the flow, so that tissue tension can be reduced. Cold compresses to reduce edema due to interstitium fluid that has accumulated out of the veins into the tissues so that pain is reduced (Arora et al., 2008).

The weakness of breastcare method was warm compress is done after breast massage. Breast engorgement case had more painful if the breast massage is done directly before warm compress. It can do it before breast to reduce breast pain. Beside that temperatures of warm and cold compresses were less than two minutes.

\section{CONCLUSION}

Among postpartum mother with breast engorgement, Herbal care packages and breastcare method could increase volume of breast milk. Herbal care packages is greater than breastcare method to increase volume of breast milk. Future researchers can add other 


\section{STRADA Jurnal Ilmiah Kesehatan}

DOI: $10.30994 /$ sjik.v9i2.387

ISSN: 2252-3847 (print); 2614-350X (online)

Vol.9 No.2 November 2020 Page.813-819

variables related volume of breast milk like nutritional and psychological patterns of the mother.

\section{REFERENCES}

Alekseev, N. P., Vladimir, I. I., \& Nadezhda, T. E.(2015). Pathological postpartum breast engorgement: prediction, prevention, and resolution. Breastfeeding medicine : the official journal of the Academy of Breastfeeding Medicine, 10(4), 203-208.

Arora, S., Vatsa, M., \& Dadhwal, V.(2008). A Comparison of Cabbage Leaves vs. Hot and Cold Compresses in the Treatment of Breast Engorgement. Indian journal of community medicine : official publication of Indian Association of Preventive \& Social Medicine, 33(3), 160-162.

Bahiyatun.(2013). Buku Ajar Asuhan Kebidanan Nifas Normal.Jakarta : Penerbit Buku Kedokteran EGC.

Dhippayom, T., Kongkaew, C., Chaiyakunapruk, N., Dilokthornsakul, P., Sruamsiri, R., Saokaew, S., . . . Medicine, A.(2015). Clinical Effects Of Thai Herbal Compress: A Systematic Review And Meta-Analysis. Evidence Based Complementar Journal, 2015.

Disha, A. R., Singh, A., \& Suri, V.(2015). Effect Of Chilled Cabbage Leaves Vs. Hot Compression On Breast Engorgement Among Post Natal Mothers Admitted In A Tertiary Care Hospital. Nursing Midwifery Research, 11(1), 24.

ElSaidy, T. M. K., \& Aboushady, R. M. N.(2016). Effect Of Two Different Nursing Care Approaches On Reduction Of Breast Engorgement Among Postnatal Women. Journal of Nursing EducationPractice, 6(9), 18.

Hill, P. D., \& Humenick, S. S.(1994). The Occurrence of Breast Engorgement. Journal of Human Lactation, 10(2), 79-86.

Kemenkes, R. I.(2018a). Laporan Nasional Riset Kesehatan Dasar (RISKESDAS). Jakarta: Badan Penelitian dan Pengembangan Riset Daerah.

Kemenkes, R. I.(2018b). Profil Kesehatan Indonesia 2017. Jakarta: Kementerian Kesehatan Republik Indonesia.

Ketsuwan, S., Baiya, N., Paritakul, P., Laosooksathit, W., \& Puapornpong, P.(2018). Effect of Herbal Compresses for Maternal Breast Engorgement at Postpartum: A Randomized Controlled Trial. Breastfeeding Medicine, 20, 1-5.

Lim, A. R., Song, J.-A., Hur, M.-H., Lee, M.-K., \& Lee, M. S.(2015). Cabbage compression early breast care on breast engorgement in primiparous women after cesarean birth: a controlled clinical trial. International journal of clinical and experimental medicine, 8(11), 21335-21342.

Mangesi, L., \& Zakarija Grkovic, I.(2016). Treatments For Breast Engorgement During Lactation. Cochrane Database of Systematic Reviews(6).

Manna, M., Podder, L., \& Devi, S.(2016). Effectiveness of hot fomentation versus cold compression on breast engorgement among postnatal mothers. International Journal of Nursing Research and Practice, 3(1), 13-17.

Maritalia, D.(2012). Asuhan Kebidanan Nifas dan Menyusui. Yogyakrta: Pustaka Pelajar. 67-73.

Novita, R. V.(2011). Efektifitas Paket "Bunda Ceria" terhadap Rasa Nyeri dan Pembengkakan Payudara serta Produksi ASI pada Ibu Post Partum di Jakarta[thesis]. Jakarta: Universitas Indonesia; 2011. 


\section{STRADA Jurnal Ilmiah Kesehatan}

DOI: $10.30994 /$ sjik.v9i2.387

ISSN: 2252-3847 (print); 2614-350X (online)

Vol.9 No.2 November 2020 Page.813-819

Odom, E. C., Li, R., Scanlon, K. S., Perrine, C. G., \& Grummer-Strawn, L.(2013). Reasons for Earlier Than Desired Cessation of Breastfeeding. Pediatrics, 131(3), e726-e732.

Pamela Berens, W. B.(2016). ABM Clinical Protocol \#20: Engorgement, Revised 2016. 159-153.

Panwara, P., Kasem, R., Wipada, L., Maysita, S., \& Pawin, P.(2016). The Effect of Ginger on Breast Milk Volume in the Early Postpartum Period: A Randomized, DoubleBlind Controlled Trial. 11(7), 361-365.

Prawirohardjo, S.(2014). Ilmu Kebidanan Jakrta: Yayasan Bina Pustaka, 700.

Soonanond, M.(2014). Thai Traditional Medicine in the Faculty of Medicine Siriraj Hospital. Supavanich Press, 49.

Trainapakul, C., Chaiyawattana, M., \& Kanavitoon, W.(2010). Effect of milk ejection performance of postpartum mothers after breasts massage and compression with mini hot bag and herbal compress. Journal of Nursing Education, 3, 75-91.

Witt, A. M., Bolman, M., Kredit, S., \& Vanic, A.(2016). Therapeutic Breast Massage in Lactation for the Management of Engorgement, Plugged Ducts, and Mastitis. 32(1), 123-131. 